The Role of employee satisfaction in enhancing employee' performance-An empirical study on a sample of pharmacies of the state of Khenchela (Algeria)-

\begin{abstract}
:
The aim of this study is to empirically examine the employee satisfaction and its relationship with the enhancing of employee performance in Algerian pharmacies. We found that: "employee satisfaction" is positively associated with "employee performance" in Algerian pharmacies. There is a statistically significant difference amongst the employees in Algerian pharmacies due to privacy determinants (gender, experience, and education level).

Key words: employee satisfaction, employee performance, Algerian pharmacies.
\end{abstract}

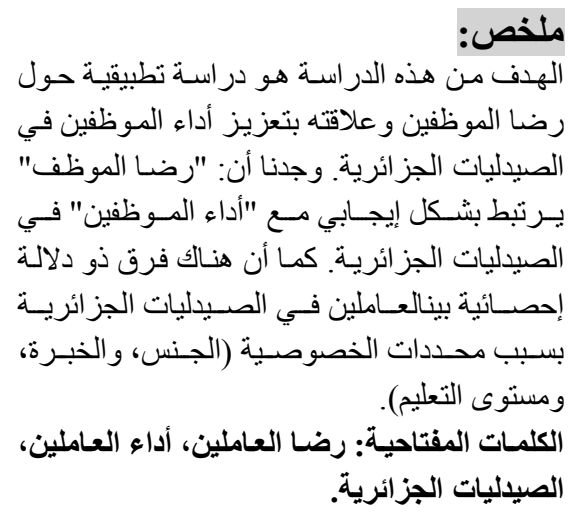

\section{Dr.Adjali Dalal}

Département de Sciences Economie

Université Abbes Laghrour

Khenchela

\begin{abstract}
Introduction :
There has been a great deal of research conducted on how organizations can become more competitive and profitable. Part of that research indicates that there are two factors that successful companies share: employee satisfaction and strong performance for employees ${ }^{1}$.
\end{abstract}


The concept of employee performance has received considerable scholarly research attention over the past 15 to 20 years. Researchers agree that employee performance has to be considered as a multi-dimensional concept ${ }^{2}$. It must be distinguished from effectiveness and from productivity or efficiency 3 . And a great deal of attention has been paid to the distinction between task and contextual and adaptive performance. Where task performance covers a person's contribution to organizational performance and contextual performance consists of behavior that does not directly contribute to organizational performance but supports the organizational, social and psychological environment. However, due to changing and dynamic work environments, the need for adaptive employees has become increasingly important ${ }^{4}$. And to enhance this performance they need to be satisfied with their employee.

Research problem:

This research paper tries to explore the importance and the relationship between the satisfaction of employees and their performance in Algerian Pharmaceutical organizations. And we choose the state of khenchela as a sample.

So, we can ask the main question of this research, which is: what is the role of employee satisfaction in enhancing their performance in Algerian Pharmaceutical organizations?

Research model:

To seek the research object, we can present the factors affecting employee performance of Pharmaceutical organizations in our model of research:

\begin{tabular}{|l|l|}
\hline \multicolumn{3}{|c|}{ Independent Variable } & $\begin{array}{l}\text { Dependent } \\
\text { Variable }\end{array}$ \\
\hline $\begin{array}{l}\text { employee satisfaction in Algerian Pharmaceutical } \\
\text { organizations }\end{array}$ & $\begin{array}{l}\text { employee } \\
\text { performance }\end{array}$ \\
\hline $\begin{array}{l}\text { rewards/pay in Algerian Pharmaceutical } \\
\text { organizations; in Algerian Pharmaceutical } \\
\text { promotion } \\
\text { organizations; } \\
\text { Safety and securityin Algerian Pharmaceutical } \\
\text { organizations; with supervisorsin Algerian } \\
\text { relationship }\end{array}$ & \\
$\begin{array}{l}\text { Pharmaceutical organizations; } \\
\text { relationship with co-workersin Algerian } \\
\text { Pharmaceutical organizations; }\end{array}$ & \\
\hline
\end{tabular}

\section{Research hypotheses:}

We developed four principle hypotheses to test that interrelation and impact:

H1. The statistical tests used in this research proving the existence of "employee satisfaction" in Algerian pharmaceutical organizations; 
The Role of employee satisfaction in enhancing employee' performance- An empirical study on a sample of pharmacies of the state of Khenchela (Algeria)-

H2. The statistical tests used in this research proving the existence of the "employee performance" in Algerian pharmaceutical organizations;

H3. The statistical tests used in this research proving the relationship between "employee satisfaction" and "employee performance" in Algerian pharmaceutical organizations;

H4. There is a statistically significant difference amongst Algerian pharmaceutical organizations due to privacy determinants (gender, experience, and education level).

The objectives of our research:

- To determine the existence the employee satisfaction and performance in Algerian pharmaceutical organizations;

- To determine the level of satisfaction between the employees in pharmaceutical organizations, and the degree of difference between pharmacists and other qualifications;

- To test the relation and the impact of employee satisfaction on their competences in Algerian pharmaceutical organizations.

\section{Literature Review}

\section{Employee performance:}

\subsection{Definition of employee performance:}

It is defined as the outcome or contribution of employees to make them attain goals ${ }^{5}$ while performance may be used to define what an organization has accomplished with respect to the process, results, relevance and success Uganda National Development Program (1995). Also it can be defined as the achievement of specific tasks measured against predetermined or identified standards of accuracy, completeness, cost and speed ${ }^{6}$. Employee performance can be manifested in improvement in production, easiness in using the new technology, highly motivated workers ${ }^{7}$. It is normally looked at in terms of outcomes. However, it can also be looked at in terms of behavior ${ }^{8}$. Employee performance is defined as a role of the individual's performance on particular objectives that consist of defined standard employee descriptions ${ }^{9}$. And it is of high relevance for organizations and individuals alike. Showing high performance when accomplishing tasks results in satisfaction, feelings of self efficacy and mastery ${ }^{\mathbf{1 0}}$.

\subsection{Employee performance measure:}

A variety of measures of employee performance has been used over the past decades ${ }^{11}$. For example, rating scales, tests of employee knowledge, hands-on employee samples, and archival records have been used to assess employee performance ${ }^{12}$. From these measurement options, performance ratings (e.g. peer ratings and supervisor ratings) are the most frequent way of measuring employee performance ${ }^{13}$. Often, 'objective' criteria such as sales figures and production records are requested. However, even these criteria involve 
subjective judgments of which specific type of criteria pictures performance ${ }^{14}$ and are, like other performance measures, not perfect ${ }^{15}$.

Using meta-analysis, Viswesvaran et aI. (1996) compared the reliability of supervisor ratings and peer ratings. They concluded that supervisory ratings showed higher interrater reliability than peer ratings ${ }^{\mathbf{1 6}}$.

\subsection{Performance appraisal:}

Performance appraisal is a process that is carried out to enable both the individual and the organization to analyze, examine and evaluate the performance of specified objectives over a period of time. This process can take up formal and informal forms ${ }^{17}$. The purposes of performance appraisal have been classified into two groups that is the developmental and administrative purposes. The developmental purposes of performance appraisal include providing performance feedback, identifying individual strengths/weaknesses, recognizing individual performance, assisting in goal identification, evaluating goal achievement identifying individual training needs, determining organizational training needs, improving communication and allowing employees to discuss concerns. On the other hand, administrative Under the developmental purposes are purposes of performance appraisal include but are not limited to documenting personal decisions, determining promotion candidates, determining transfers and assignments, identifying poor performance, deciding layoffs, validating selection criteria, meeting legal requirements to mention a few ${ }^{18}$.

\subsection{Factors Affecting Employee Performance:}

According to some researchers and practitioners, there are certain factors individually and collectively effect on the performance of employees in a positive or negative way, including:

- Leadership: The leadership style within an organization has a bearing on encouraging or inhibiting employee's performance ${ }^{19}$.

- Coaching: Coaching has become an important technique to improve performance ${ }^{20}$. It addresses the belief and behaviors that hinder performance ${ }^{21}$.

- Empowerment: it had significant positive correlations with both performance and satisfaction ${ }^{22}$.

- Participation: The overall impact of participation is increased employee performance and low turn-over.

- Organizational Culture: Strong culture in the organization is very helpful to enhance the performance of the employees that leads to the goal achievement and increase the overall performance of the organization ${ }^{23}$.

\section{Employee satisfaction:}

Despite its vide usage in scientific research, as well as in everyday life, there is still no general agreement regarding what employee satisfaction is. 


\section{The Role of employee satisfaction in enhancing employee' performance- An empirical study on a sample of pharmacies of the state of Khenchela (Algeria)-}

In fact there is no final definition on what employee represents. Therefore before a definition on employee satisfaction can be given, the nature and importance of work as a universal human activity must be considered.

The term employee satisfactions refers to the attitude and feelings people have about their work. Positive and favorable attitudes towards the employee indicate employee satisfaction. Negative and unfavorable attitudes towards the employee indicate employee dissatisfaction ${ }^{24}$. Employee satisfaction can be defined also as the extent to which a worker is content with the rewards he or she gets out of his or her employee, particularly in terms of intrinsic motivation 25 .

Employee satisfaction is defined as the extent to which employees like their work. Based on perceptions, an employee develops a positive or negative attitude towards their employee and environment. Also it is defined as a pleasurable or positive emotional state resulting from the appraisal of one's employee or employee experiences ${ }^{\mathbf{2 6}}$.

3.Employee Satisfaction and Performance Relationship:

The relationship between employee satisfaction and performance has been critically assessed in a variety of organizational settings. Cummings (1970) identified three major points of view concerning this relationship. Satisfaction causes performance, performance causes satisfaction and rewards cause both performance and satisfaction. Kornhanuser and Sharp (1976) have conducted more than thirty studies to identify the relationship between satisfaction and performance in industrial sector. Many of the studies have found that a positive relationship existed between employee satisfaction and performance. Smith and Cranny (1968) reviewed the literature and concluded that satisfaction is associated with performance as well as effort, commitment and intention. Porter and Lowler (1969) suggested that satisfaction will affect a worker's effort, arguing that increased satisfaction from performance possibility helps to increase expectations of performance leading to rewards. Carroll, Keflas and Watson (1964) found that satisfaction and productivity are crucial relationship in which each affects the other. They suggest that performance leads to more effort because of high perceived expectancy. The effort leads to effective performance, which again leads to satisfaction in crucial relationship. David, Joseph and William (1970) suggest that the type of reward system under which workers perform strongly influence the satisfaction performance relationship ${ }^{27}$. 4. Impact of employee Satisfactiondeterminants on their performance: Here, we address various determinants of employee satisfaction and their impact on employee performance.

Job satisfaction is an outcome of different factors like pay, promotion, the work itself, supervision, relationships with co-workers and opportunities for promotions ${ }^{28}$. 
4.1. Impact of rewards/pay on employee performance:

One of the most important factors is pay. ${ }^{29}$ found that there is positive relationship between equity based compensation and performance. Here are some empirical evidences that there is positive correlation between compensation and performance ${ }^{30}$.

\subsection{Impact of promotion on employee performance:}

Teseema and Soeters concluded that there is positive relationship between promotion practices and perceived performance of employee ${ }^{31}$.

4.3. Impact of job safety and security onemployee performance:

Important factors like low job security, working conditions and the nature of work, low wages and lack of promotion, low job autonomy have adverse affect on the level of job satisfaction of employees (Guest, 2004; Silla et al.,2005).

4.4. Impact of working conditions on and employee performance:

The researcher found that work environment is an important determinant of job satisfaction of employees ${ }^{33}$.

4.5. Impact of relationship with co-workers on employee performance: James concluded that the working as a team has significant impact on the satisfaction level of employees as it affects their performance ${ }^{34}$.

4.6. Impact of relationship with supervisors on employee performance:

The productivity and performance of the subordinates is significant toward the managerial actions and supervision of the workers ${ }^{35}$.

4.7. Impact of nature of work on job satisfaction and performance:

Robbins et al. refer to the work itself as "the extent to which the job provides the individual with stimulating tasks, opportunities for learning and personal growth, and the chance to be responsible and accountable for results" ${ }^{\text {"36. }}$.

5. Research methodology:

5.1. Instruments of the research:

Table (1) describes the dimensions of the study. Where we have been relying on questionnaire includes 4 fields and 26 items, to be briefing the components of employee satisfaction and their competences in Algerian pharmaceutical organizations. 
The Role of employee satisfaction in enhancing employee' performance-An empirical study on a sample of pharmacies of the state of Khenchela (Algeria)-

\subsection{Sampling:}

Table (1): Dimensions of the research.

\begin{tabular}{clc}
\hline $\mathbf{N}^{\mathbf{0}}$ & \multicolumn{1}{c}{ Dimension } & $\begin{array}{c}\text { No. of } \\
\text { Items }\end{array}$ \\
\hline $\mathbf{1}$ & $\begin{array}{l}\text { Rewards/pay and safety in Algerian Pharmaceutical } \\
\text { organizations. }\end{array}$ & $\mathbf{5}$ \\
$\mathbf{2}$ & $\begin{array}{l}\text { Relationship with supervisorsin Algerian Pharmaceutical } \\
\text { organizations. }\end{array}$ & $\mathbf{7}$ \\
$\mathbf{3}$ & $\begin{array}{l}\text { relationship with co-workersin Algerian Pharmaceutical } \\
\text { organizations; }\end{array}$ & $\mathbf{5}$ \\
$\mathbf{4}$ & \begin{tabular}{l} 
Employees Competences \\
\multicolumn{2}{c}{ Total }
\end{tabular} & $\mathbf{9}$ \\
\hline
\end{tabular}

Sampling techniques can be divided into two types: probability and non probability sampling ${ }^{37}$. In this research, we prefer to use probability sampling. We are used a simple random sample, where 83 employee in 16 Pharmaceutical organizations in the State of khenchela were surveyed and 51 employee responded (response rate $61.44 \%$ ).

\section{The statistical treatment used in our research:}

For each type of measurement there is an appropriate method that can be applied and not others. As table (2) illustrate, in this research, we use the ordinal scales, which is a ranking or a rating data that normally uses integers in ascending or descending order. The numbers assigned to the importance $(1,2,3,4,5)$ do not indicate that the interval between scales are equal, nor do they indicate absolute quantities. They are merely numerical labels.

Table (2): The Likert scale model in answering the questionnaire

\begin{tabular}{cc}
\hline Weight & Descriptive interpretations \\
\hline $\mathbf{5}$ & Strongly agree \\
$\mathbf{4}$ & agree \\
$\mathbf{3}$ & neutral \\
$\mathbf{2}$ & disagree \\
$\mathbf{1}$ & Strongly disagree \\
\hline
\end{tabular}

In statistical treatment of the instrument of our research we use KolmogorovSmirnov test of normality, validity to choosing tests that suite our research. From table (3), the p-value for each field is smaller than 0.05 the level of significance, then the distribution of each one is not normally distributed and the instrument of research (questionnaire) is valid, so it can be used to measure what it supposed to be measuring ${ }^{38}$. 
Table (3): Kolmogorov-Smirnov Test of Normality, Validity and reliability

\begin{tabular}{|ll|l|l|l|}
\hline & & \multicolumn{3}{|l|}{ Kolmogorov-Smirnov ${ }^{\mathbf{a}}$} \\
\cline { 4 - 6 } & & Statistique & ddd & $($ Sig) \\
\hline - Rewards/pay and safety in Algerian &, 130 & 51 & 0.031 \\
Pharmaceutical organizations. &, 232 & 51 & 0.000 \\
- Relationship with supervisorsin Algerian &, 158 & 51 & 0.003 \\
Pharmaceutical organizations. &, 222 & 51 & 0.000 \\
- relationship with co-workersin Algerian & & & \\
Pharmaceutical organizations & & & \\
- Employees Competences. & & & \\
\hline a. La distribution à tester est gaussienne. \\
b. Calculée à partir des données.
\end{tabular}

Consequently, we will use non-parametric tests to analyze the statistical data of this research. The data will be analyzed by (spss), and we would utilize the following statistical tests:

- Cronbach's Alpha to test the reliability statistics;

- Spearman rank to test the correlation coefficient;

- Frequency and descriptive analysis;

- Nonparametric tests.

\section{Questionnaire:}

7.1. Questionnaire validity and reliability:

The statistical validity of the questionnaire is used to evaluate the instrument validity for using it in measuring what it supposed to be measuring. And it refers to the correlation degree between each field in the questionnaire and the whole questionnaire, what is named structure validity.

In table (4) we have tested the structure validity of the questionnaire by using Spearman Rank Correlation Test for Validity to calculate the correlation coefficient for the questionnaire. The result shows that, there is a high degree of consistence and validity of the instrument of research (questionnaire). Where the test of Spearman-Brown gives high levels of correlation they were in the range from 0.790 and 0.797 , and (Cronbach's Alpha the test of reliability statistics is equal to 0,655$)$, and split half the test of reliability is equal to 0,790).

Table (4): validity of the questionnaire (Split Half Method).

\begin{tabular}{|l|l|l|r|}
\hline \multirow{4}{*}{ Alpha de Cronbach } & Partie 1 & Valeur &, 029 \\
\cline { 2 - 3 } & & Nombre d'éléments & $3^{\mathrm{a}}$ \\
\cline { 2 - 4 } & Partie 2 & Valeur &, 792 \\
\cline { 2 - 3 } & & Nombre d'éléments & $2^{\mathrm{b}}$ \\
\hline & Nombre total d'éléments & 5 \\
\hline & \multicolumn{2}{|c|}{ Corrélation entre les sous-échelles } \\
\hline
\end{tabular}


The Role of employee satisfaction in enhancing employee' performance-An empirical study on a sample of pharmacies of the state of Khenchela (Algeria)-

\begin{tabular}{|c|c|c|}
\hline \multirow{2}{*}{$\begin{array}{l}\text { Coefficient de } \\
\text { Spearman-Brown }\end{array}$} & Longueur égale & ,792 \\
\hline & Longueur inégale & ,797 \\
\hline \multicolumn{2}{|c|}{ Coefficient de Guttman split-half } &, 790 \\
\hline \multicolumn{3}{|c|}{$\begin{array}{l}\text { a. the elements are: rewards and pay, Relationship with supervisors in } \\
\text { Algerian } \\
\text { Pharmaceutical organizations., Relationship with the team. }\end{array}$} \\
\hline \multicolumn{3}{|c|}{$\begin{array}{l}\text { b. the elements are: Relationship with the team, Efficiency of work } \\
\text { performance, all questionnaire. }\end{array}$} \\
\hline
\end{tabular}

\subsection{Profile of the study sample:}

To perform the aim of our research we choose some profiles of the study sample table (5), which includes the gender of employees in Algerian pharmaceutical organizations, their specialties, and their experience, to illustrate the impact of these profiles on the employee's competences in these organizations.

Table (5): Profile of the study sample.

\begin{tabular}{lrc}
\hline Gender & Frequency & Percent \\
\hline Male & 32 & 63 \\
Female & 19 & 37 \\
Total & 51 & 100.00 \\
experience & Frequency & Percent \\
Less than 5 years & 20 & 39 \\
Between 5 to 10 years & 6 & 12 \\
More than 10 years & 25 & 49 \\
Total & 51 & 100.00 \\
Specialty & Frequency & Percent \\
Pharmacist & 32 & 63 \\
Other specialty & 19 & 37 \\
Total & $\mathbf{5 1}$ & $\mathbf{1 0 0}$ \\
\hline
\end{tabular}

8. Results of research:

H.1: The statistical tests used in this research proving the existence of "employee satisfaction" in Algerian pharmaceutical organizations. This hypothesis can be divided into the following sub-hypothesis:

H1a: There is statistically significant on the existence of "awards and safety in Algerian pharmaceutical organizations". Table (6) shows these results:

The mean of paragraphs number $(5,2$ and1) are successively equal to $(3.37$, 3.25 and 3.10) their S.D $=(0.979,1.185$ and 1.446), and their test value $=(24.602,15.303$, and 19.689), and their $\mathrm{p}$-value $=0.00$ which is smaller than the level of significance $\alpha=0.05$. So we can conclude that the employees in 
Algerian pharmaceutical organizations are neutral to these paragraphs, because its mean is less than 4 and the sign of its test is positive.

The mean of paragraphs number (3and 4) are successively equal to (2.84 and $2.61)$ their $\mathrm{S} . \mathrm{D}=(1.065$ and 0.874$)$, and their test value $=(19,059$ and 21.319$)$, and their $\mathrm{p}$-value $=0.00$ which is smaller than the level of significance $\alpha=0.05$. So we can conclude that the employees in Algerian pharmaceutical organizations are disagree to these paragraphs, because its mean is less than 3 and the sign of its test is positive.

The mean of the existence of awards and safety in Algerian pharmaceutical organizations" is equal to 3.034 and its $\mathrm{P}$ value $=0.000$. So we can conclude that the employees in Algerian pharmaceutical organizations are neutral to this paragraph, because its mean is equal to 3 and the sign of its test is positive.

Table (6): mean and test values for "awards and safety in Algerian pharmaceutical organizations".

\begin{tabular}{lllllll}
\hline $\mathbf{N}$ & \multicolumn{1}{c}{ Items } & Mean & S.D & $\begin{array}{l}\text { Test } \\
\text { value }\end{array}$ & $\begin{array}{l}\text { p- } \\
\text { value }\end{array}$ \\
\hline $\mathbf{1}$ & $\begin{array}{l}\text { I am satisfied with my salary and } \\
\text { compensation. }\end{array}$ & 3.10 & 1.446 & 15.303 & 0.00 \\
$\mathbf{2}$ & $\begin{array}{l}\text { I am satisfied with the security level } \\
\text { provided in the organization. }\end{array}$ & 3.25 & 1.185 & 19.689 & 0.00 \\
$\mathbf{3}$ & $\begin{array}{l}\text { The organization contributes to } \\
\text { professional development }\end{array}$ & 2.84 & 1.065 & 19.059 & 0.00 \\
$\mathbf{4}$ & $\begin{array}{l}\text { The organization offers special training } \\
\text { at its own expense. }\end{array}$ & 2.61 & 0.874 & 21.319 & 0.00 \\
$\mathbf{5}$ & $\begin{array}{l}\text { The organization is interested in } \\
\text { encouraging continuous learning. }\end{array}$ & 3.37 & 0.979 & 24.602 & 0.00 \\
$\mathbf{6}$ & All paragraphs & 3.034 & 0.787 & 22.654 & 0.00 \\
\hline
\end{tabular}

H1b: There is statistically significant on the existence of "relationship between supervisor and the employees Algerian pharmaceutical organizations". Table (7) shows the following results:

The mean of paragraphs number $(1,3,4$ and 2$)$ are successively equal to (4.76, $4.47,4.08)$ their $\mathrm{S} . \mathrm{D}=(0.651,0.504,0.796)$, and their test value $=(52.285$, $63.33,34.890,35.263)$, and their $\mathrm{p}$-value $=0.00$ which is smaller than the level of significance $\alpha=0.05$. So we can conclude that the employees in Algerian pharmaceutical organizations are strongly agreeing to these paragraphs, because its mean is greater than 4 and the sign of its test is positive. Also, the mean of paragraphs number $(5,6)$ are successively equal to $(3.73$, and 3.14$)$ their S.D $=(0.961,1.040)$, and their test value $=(27.691,21.551)$, and their $\mathrm{p}-$ value $=0.00$ which is smaller than the level of significance $\alpha=0.05$. So we can 
The Role of employee satisfaction in enhancing employee' performance-An empirical study on a sample of pharmacies of the state of Khenchela (Algeria)-

conclude that the employees in Algerian pharmaceutical organizations are neutral to these paragraphs, because its mean is less than 4 and the sign of its test is positive.

The mean of the existence of relationship between employers and their employees in Algerian pharmaceutical organizations" is equal to 4.081 and its $\mathrm{P}$ value $=0.000$. So we can conclude that the employees in Algerian pharmaceutical organizations are agreeing to this paragraph, because its mean is equal to 4 and the sign of its test is positive.

Table (7): mean and test values for "Good relationship between employers and their employees in Algerian pharmaceutical organizations".

\begin{tabular}{llllll}
\hline $\mathbf{N}$ & \multicolumn{1}{c}{ Items } & Mean & S.D & $\begin{array}{l}\text { Test } \\
\text { value }\end{array}$ & $\begin{array}{l}\text { p- } \\
\text { value }\end{array}$ \\
\hline $\mathbf{1}$ & $\begin{array}{l}\text { I am satisfied with my relationship with } \\
\text { the employer. }\end{array}$ & 4.76 & 0.651 & 52.285 & 0.00 \\
$\mathbf{2}$ & $\begin{array}{l}\text { I am satisfied with the level of } \\
\text { respectful treatment of workers at } \\
\text { different levels }\end{array}$ & 4.08 & 0.796 & 35.263 & 0.00 \\
$\mathbf{3}$ & $\begin{array}{l}\text { I am satisfied with the level of trust } \\
\text { between the employees and the employer } \\
\mathbf{4}\end{array}$ & 4.47 & 0.504 & 63.333 & 0.00 \\
$\mathbf{T}$ & $\begin{array}{l}\text { of the employer recognizes the efficiency } \\
\text { I am satisfied with the level and type of } \\
\text { dialogue between the employee and the } \\
\text { employer }\end{array}$ & 3.31 & 0.883 & 34.890 & 0.00 \\
$\mathbf{6} \quad \begin{array}{l}\text { The objectives and strategy of the } \\
\text { organization are discussed with the staff } \\
\text { All paragraphs }\end{array}$ & 3.14 & 1.040 & 21.551 & 0.00 \\
\hline $\mathbf{7}$ & 4.081 & 0.652 & 36.587 & 0.00 \\
\hline
\end{tabular}

H1c: There is statistically significant on the existence of "goodrelations inside the work teams of Algerian pharmaceutical organizations". Table (8) shows the following results:

Table (8): mean and test values for "Good relationship inside the work teams in Algerian pharmaceutical organizations".

\begin{tabular}{|c|c|c|c|c|c|}
\hline $\mathbf{N}$ & Items & Mean & S.D & $\begin{array}{l}\text { Test } \\
\text { value }\end{array}$ & $\begin{array}{l}\text { p- } \\
\text { value }\end{array}$ \\
\hline 1 & $\begin{array}{l}\text { with my relationship with } \\
\mathrm{ff}\end{array}$ & 4.71 & 0.460 & 73.030 & 0.00 \\
\hline 2 & $\begin{array}{l}\text { I am satisfied with my mutual trust with } \\
\text { my colleagues }\end{array}$ & 4.69 & 0.735 & 45.559 & 0.00 \\
\hline 3 & We have a cohesive team and I do not & 4.06 & 1.121 & 25.859 & 0.00 \\
\hline
\end{tabular}




\section{Dr.Adjali Dalal}

\begin{tabular}{llllll}
\hline & & & & & \\
\hline & want to break away from them & & & & \\
$\mathbf{4}$ & $\begin{array}{l}\text { When making a decision all the } \\
\text { members of the team contributes }\end{array}$ & 4.08 & 0.796 & 36.587 & 0.00 \\
$\mathbf{5}$ & Staff have the necessary autonomy & 4.16 & 0.784 & 37.857 & 0.00 \\
$\mathbf{6}$ & All paragraphs & 4.34 & 0.659 & 25.361 & 0.00 \\
\hline
\end{tabular}

The mean of paragraphs arranged between 4.06 and 4.71, and their $\mathrm{P}$ value $=0.000$. So we can conclude that the employees in Algerian pharmaceutical organizations are strongly agreeing to these paragraphs, because their means are bigger than 4 and the sign of its test are positive.

H2. There is statistically significant on the existence of "employee performance" in Algerian pharmaceutical organizations; Table (9) shows the following results:

Table(9): mean and test values for "employee performance in Algerian pharmaceutical organizations".

\begin{tabular}{llllll}
\hline $\mathbf{N}$ & Mean & S.D & $\begin{array}{l}\text { Test } \\
\text { value }\end{array}$ & $\begin{array}{l}\text { p- } \\
\text { value }\end{array}$ \\
\hline $\mathbf{1}$ & $\begin{array}{l}\text { Work is done according to the required } \\
\text { level in terms of accuracy, completion, } \\
\text { cost and speed. }\end{array}$ & 0.20 & 0.63 & 43.217 & 0.00 \\
$\mathbf{2}$ & $\begin{array}{l}\text { Employees contribute to improving the } \\
\text { profitability of the organization }\end{array}$ & 4.20 & 0.693 & 43.217 & 0.00 \\
$\mathbf{3}$ & $\begin{array}{l}\text { Contributing staff in providing high } \\
\text { quality services. }\end{array}$ & 4.22 & 0.702 & 42.897 & 0.00 \\
$\mathbf{4}$ & $\begin{array}{l}\text { Employees have the ability to use } \\
\text { modern technology easily and } \\
\text { efficiently. }\end{array}$ & & 0.917 & 32.222 & 0.00 \\
$\mathbf{5}$ & $\begin{array}{l}\text { Employees deal with emergencies, } \\
\text { crises, work pressures and uncertainties. }\end{array}$ & 4.08 & 0.796 & 36.587 & 0.00 \\
$\mathbf{6}$ & $\begin{array}{l}\text { Employees have the ability to solve } \\
\text { problems creatively }\end{array}$ & 4.02 & 0.720 & 39.284 & 0.00 \\
$\mathbf{7}$ & $\begin{array}{l}\text { Staff have the ability to adapt } \\
\text { collectively and culturally }\end{array}$ & 4.08 & 0.627 & 46.417 & 0.00 \\
$\mathbf{8}$ & $\begin{array}{l}\text { Employees have the desire and ability to } \\
\text { learn continuously }\end{array}$ & 4.20 & 0.849 & 35.296 & 0.00 \\
$\mathbf{9}$ & All paragraphs & 4.15 & 0.652 & 43.256 & 0.00 \\
\hline
\end{tabular}

The mean of paragraphs arranged between 4.02 and 4.22, and their $\mathrm{P}$ value $=0.000$. So we can conclude that the employees in Algerian pharmaceutical organizations are strongly agreeing to these paragraphs, because their means are bigger than 4 and the sign of its test are positive. 
The Role of employee satisfaction in enhancing employee' performance- An empirical study on a sample of pharmacies of the state of Khenchela (Algeria)-

H3. There is statistically significant on the relationship between "employee satisfaction" and "employee performance" in Algerian pharmaceutical organizations; this hypothesis can be divided into the following subhypotheses:

H3a. There is a statistically significant relationship between "Rewards \&pay" and the "employee performance" in Algerian pharmaceutical organizations. The table (10) of spearman coefficient correlation shows Test value $=\mathbf{- 0 . 2 5 6}$ the p-value (sig) $=\mathbf{0 . 6 9}$ which is bigger than the level of significance 0.05 . The sign of test is negative, so there is no statistically significant relationship between "Rewards \&pays in Algerian pharmaceutical organizations" and the "employee performance" amongst Algerian pharmaceutical organizations.

H3b. There is a statistically significant relationship between the "Relationship with supervisors" and the "employee performance", in Algerian pharmaceutical organizations.

The table (10) of spearman coefficient correlation shows Test value $=+\mathbf{0 . 6 2 5}$ the $p$-value $(\mathrm{sig})=0.03$ which is smaller than the level of significance 0.05 . The sign of test is positive, so there is a statistically significant relationship between "Relationship with supervisors" and "efficiency work performance"

H3c. There is a statistically significant relationship between the "Relationship with the teamwork" and the "employee performance", in Algerian pharmaceutical organizations.

The table (10) of spearman coefficient correlation shows Test value $=+\mathbf{0 . 9 4 8}$ the $p$-value (sig) $=0.00$ which is smaller than the level of significance 0.05 . The sign of test is positive, so there is a statistically significant relationship between "Relationship with teamwork" and the "employee performance".

Table (10): correlation coefficient of each field and the whole of questionnaire

\begin{tabular}{|c|c|c|c|c|c|c|}
\hline & & $\begin{array}{l}\text { Rewar } \\
\text { ds } \\
\text { \&pay }\end{array}$ & $\begin{array}{l}\text { Relations } \\
\text { hip with } \\
\text { superviso } \\
\text { rs }\end{array}$ & $\begin{array}{l}\text { Relations } \\
\text { hip with } \\
\text { the } \\
\text { teamwor } \\
\mathbf{k}\end{array}$ & $\begin{array}{l}\text { Employee } \\
\text { performa } \\
\text { nce }\end{array}$ & $\begin{array}{l}\text { All } \\
\text { quitionna } \\
\text { ire }\end{array}$ \\
\hline \multirow[t]{3}{*}{$\begin{array}{l}\text { awards } \\
\text { and safety }\end{array}$} & $\begin{array}{l}\text { Co } \\
\text { ef }\end{array}$ & 1.00 & -0.263 & -0.19 & -0.256 & 0.176 \\
\hline & $\begin{array}{l}\text { (Si } \\
\text { g) }\end{array}$ & $\ldots$ & 0.63 & 0.893 & 0.690 & 0.217 \\
\hline & $\mathbf{N}$ & 51 & 51 & 51 & 51 & 51 \\
\hline \multirow{2}{*}{$\begin{array}{l}\text { Relations } \\
\text { hip with } \\
\text { superviso }\end{array}$} & $\begin{array}{l}\text { Co } \\
\text { ef }\end{array}$ & & 1.00 & 0.231 & 0.625 & 0.522 \\
\hline & (Si & & & 0.103 & 0.03 & 0.00 \\
\hline
\end{tabular}




\section{Dr.Adjali Dalal}

\begin{tabular}{|c|c|c|c|c|}
\hline \multirow[t]{2}{*}{ rs } & g) & & & \\
\hline & $\mathbf{N}$ & 51 & 51 & 51 \\
\hline \multirow{3}{*}{$\begin{array}{l}\text { Relations } \\
\text { hip with } \\
\text { the } \\
\text { teamwork }\end{array}$} & & 1.00 & 0.948 & 0.869 \\
\hline & & & 0.000 & 0.000 \\
\hline & & & 51 & 51 \\
\hline \multirow{2}{*}{$\begin{array}{l}\text { Employee } \\
\text { performa } \\
\text { nce }\end{array}$} & & & 1.00 & 0.766 \\
\hline & & & & $\begin{array}{c}0.000 \\
51\end{array}$ \\
\hline \multirow{3}{*}{$\begin{array}{l}\text { All } \\
\text { quitionna } \\
\text { ire } \\
\end{array}$} & & & 0.766 & \multirow[t]{3}{*}{1.00} \\
\hline & & & 0.000 & \\
\hline & & & 51 & \\
\hline
\end{tabular}

H4. There is a statistically significant difference amongst Algerian pharmaceutical organizations due to privacy determinants (gender, experience, and education level).

H4 a: There is a statistically significant difference amongst Algerian pharmaceutical organizations toward the employee performance due to gender as personal determinants.

Table (11) shows that the p-value (sig) $=0.000$ of all fields are smaller than the level of significance 0.05 , and then there is significant difference in respondents' answers toward these dimensions.

Table (11): Mann-Whitney test of the fields and p-value for workers' gender.

\begin{tabular}{rlcc}
\hline $\mathbf{N}^{\circ}$ & Field & Test value & (sig) \\
\hline $\mathbf{1}$ & Rewards \&pay & -8.199 & 0.000 \\
$\mathbf{2}$ & Relationship with supervisors & -9.26 & 0.000 \\
$\mathbf{3}$ & Relationship with the teamwork & -8.55 & 0.000 \\
$\mathbf{4}$ & Employee performance & -8.69 & 0.000 \\
$\mathbf{5}$ & All quitionnaire. & -8.64 & 0.000 \\
\hline
\end{tabular}

$* *$ The mean difference is significant a 0.05 level.

H4 b: There is a statistically significant difference amongst Algerian pharmaceutical organizations toward the "employee performance" due to experience of workers as personal determinants.

Table (12) shows that the p-value (sig) $=0.000$ of all fields are smaller than the level of significance 0.05 , and then there is significant difference in respondents' answers toward these dimensions. 
The Role of employee satisfaction in enhancing employee' performance-An empirical study on a sample of pharmacies of the state of Khenchela (Algeria)-

Table (12): Kruskal-Wallis test of the fields and their P-values for experience.

\begin{tabular}{rllll}
\hline $\mathbf{N}^{\circ}$ & Field & Khi-deux & N & Sig \\
\hline $\mathbf{1}$ & Rewards \&pay & 76.113 & 2 & 0.000 \\
$\mathbf{2}$ & Relationship with supervisors & 89.405 & 2 & 0.000 \\
$\mathbf{3}$ & Relationship with the teamwork & 76.0 .86 & 2 & 0.000 \\
$\mathbf{4}$ & Employee performance & 76.38 & 2 & 0.000 \\
$\mathbf{5}$ & All quitionnaire. & 100.625 & 2 & 0.000 \\
\hline & **The mean difference is significant a 0.05 level & &
\end{tabular}

H4 c: There is a statistically significant difference amongst Algerian pharmaceutical organizations toward the "employee performance" due to education level as personal determinants.

Table (13) shows that the p-value (sig) $=0.000$ of all fields are smaller than the level of significance 0.05 , and then there is significant difference in respondents' answers toward these dimensions.

Table (13): Kruskal-Wallis test of the fields and their P-values for education level.

\begin{tabular}{|c|c|c|c|c|}
\hline $\begin{array}{l}\mathbf{N} \\
0\end{array}$ & Field & $\begin{array}{l}\text { Khi- } \\
\text { deux }\end{array}$ & $\mathbf{N}$ & Sig \\
\hline 1 & Rewards \&pay & 94.207 & 2 & $\begin{array}{c}0.00 \\
0\end{array}$ \\
\hline 2 & Relationship with supervisors & $\begin{array}{l}110.01 \\
0\end{array}$ & 2 & $\begin{array}{c}0.00 \\
0\end{array}$ \\
\hline 3 & Relationship with the teamwork & $\begin{array}{l}116.96 \\
2\end{array}$ & 2 & $\begin{array}{c}0.00 \\
0\end{array}$ \\
\hline 4 & Employee performance & 88.428 & 2 & $\begin{array}{c}0.00 \\
0\end{array}$ \\
\hline 5 & All quitionnaire. & $\begin{array}{l}104.63 \\
3\end{array}$ & 2 & $\begin{array}{c}0.00 \\
0\end{array}$ \\
\hline
\end{tabular}

Conclusion:

**The mean difference is significant a 0.05 .

The previous analysis of the data revealed the following conclusions:

- Pharmacy workers in Algeria are not satisfied with the level of security provided and the level of reward granted to them, especially the pharmacists, where they receive a certain wage, and is almost equal with other whom have lower levels of education;

- Pharmacy owners are not interested in developing their workers by providing special training to avoid costs; 
- There is a good and trust-based relationship between the employer and the workers in Algerian pharmacies, but they do not share them in setting goals and developing work plans;

- There are strong relationships among workers, which greatly affects their competence;

- Pharmacists' workers have a good level of competence to deal with critical situations;

- There is a strong relationship between the efficiency of the workers and the quality of the relationship between them as a team and their relationship with the employer.

- The degree of impact of the wage paid, the relationship with the employer and the relationship with the work team differ on the efficiency of the workers in pharmacies with different sex, since the males are more sensitive to the impact of the female;

- The degree of impact of the remuneration awarded, the relationship with the employer and the relationship with the work team differ on the efficiency of the workers in the pharmacies with different experience, since the experienced are more sensitive to the impact;

- The degree of impact of the wage paid, the relationship with the employer and the relationship with the work team differ on the efficiency of the workers in pharmacies at different levels of education, as the pharmacists are more sensitive to the impact. 
The Role of employee satisfaction in enhancing employee' performance- An empirical study on a sample of pharmacies of the state of Khenchela (Algeria)-

References:

1. Abdulwahab S. Bin Shmailan, (2016), "The relationship between employee satisfaction, employee performance and employee engagement: An explorative study", Issues in Business Management and Economics", Vol.4 (1), P1.

2. Sabine Sonnentag, Judith Volmer and Anne Spychala, (2010), "Employee Performance", Micro approaches, sage handbook of organizational behavior; Vol01, edition by Julian Barling, Los angeles, Calif, 1st publication, P427.

3. Campbell, J.P, McCloy,R.A, S.H. and Sager, C.E, (1993), “A theory of performance", San Francisco, Jossey Bass,.

4. Pulakos, E.D, Arad, S., Donovan,M.A, and Plamondon, (2000), "Development of taxonomy of adaptive performance", Journal of Applied Psychology,85.

5- Hafiza et al., (2011). Relationship between rewards and Employees motivation in the nonprofit organizations of Pakistan. Business Intelligence Journal, vol. 1 No. 1. $327-335$.

6. Afshan, S., Sobia, I., Kamran, A. \& Nasir, M. (2012), "Impact of training on Employee performance: a study of telecommunication sector in Pakistan". Interdisciplinary Journal of Contemporary Research in Business 4, 6.

7. AIDAH NASSAZI, (2013), 'Effect of training on employee performance: Evidence from Uganda", economics and tourism, p13.

8. Armstrong, M. and Murlis, H.(2004). Reward management: A handbook of remuneration strategy and practice. $5^{\text {th }}$ edition. London: Kogan Page Limited.

9 Murphy, P. R. and Jackson, S. E. (1999) 'Managing Work Role Performance. Challenging the TwentyFirst Century Organizations and Their Employees', in D. R. ligen and E. D. Pulakos (eds), The Changing Nature of Performance: Implications for Staffing, Motivations, and Development. San Francisco: Jossey-Bass, pp. 325-365. 10. Benjamin Owusu, '2014), “an assessment of employee satisfaction and its effect onemployees' performance: a case of mining companiesin the [bibiani - anhwiaso bekwai district] in the western region", School of Business, KNUST.

11. Compbell et al, (1990), "Modeling the performance prediction problem in industrial and organizational psychology", Handbook of Industrial and Organizational Psychology, palo Alto: Consulting Psychologists Press, $\operatorname{Vol}(01)$.

12.Ibd.

13. Viswesvaran, C. ones, D.S. and Schmidt, F.L,( 1996), “Comparative analysis of the reliability of Employee performance rating": Journal of Applied Psychology, 81. 
14. Campbell, J. P. (1999). The definition and measurement of performance in the new age. In D. R.Ilgen \& E. D. Pulakos (Eds.), The changing nature of performance. Implications for staffing, motivation, and development(pp. 399429). San Francisco: Jossey-Bass.

15. Sabine Sonnentag et al, (2010), "Job Performance", micro approaches (sage handbook of organizational behavior), vol(01), $1^{\text {st }}$ pub, edition: Julian Barling, Los Angeles, Calif, pp427-428

16. .Ibd.,P431.

17McCourt, W. and D. Eldridge (2003) 'Performance Management and Appraisal' In McCourt Willy and Eldridge Derek (ed) Global Human Resource Management, UK: Edward Elgar Publishing limited. Pp 208-235.

18. AIDAH NASSAZI, 2013, OP, cit, P17.

19. -Armstrong, M. and Murlis, H., (2001), "Reward Management: A handbook of remuneration strategy and practice", $5^{\text {th }}$ Edition, London: Kogan Page Limited, 2004.

-Cronje, G.J, de J. du Toit, G.S. and Motlatla, M.D.C, "Introduction to Business management", $5^{\text {th }} \mathrm{Ed}$, cape Town : oxford university press South Africa.

20. Champathes,M.R, (2006), "Coaching for Performance Improvement: The Coach Model", Development and learning in Organization, Vol020, $\mathrm{N}^{\circ} 02$.

21. Toit, A. D. (2007), "Making sense through coaching". Journal of Management Development, Volume 26, No. 3, pp. 282 -291.

22. Bartram, T. \& Casimir, G. (2007). The relationship between leadership and

follower in-role performance and satisfaction with the leaders: The mediating effects of empowerment and trust in the leader. Leadership and Organization Development Journal, 28(1), pp $4-19$.

23. Deal, T.E. and kennedy, A.A, (1982), “Corporate Cultures: The Rites and Rituals of Corporate life”, Addison-Wesley, Reading, MA,.

24. Armstrong, M. (2006). A Handbook of Human resource Management Practice, Tenth Edition, Kogan Page Publishing, London, p. 264

25. Statt, D. (2004). The Routledge Dictionary of Business Management, Third edition, Routledge Publishing,Detroit, p. 78.

26. Susan Abraham(2012), 'Employee Satisfaction as an Antecedent to Employee Engagement', SIES Journal of Management, Vol. 8(2).

27. (M. D.PUSHPAKUMARI, (2008), The Impact of Employee Satisfaction on Employee Performance: An Empirical Analysis, pp91-92)

28. Opkara JO. (2002), The Impact Of Salary Differential On Managerial Job Satisfaction. A Study Of The Gender Gap And Its Implications For Management Education And Practice In A Developing Economy. J. Bus. Dev. Nation, 65-92. 
The Role of employee satisfaction in enhancing employee' performance- An empirical study on a sample of pharmacies of the state of Khenchela (Algeria)-

29. Frye MB (2004). Equity-based compensation for employees. Firm performance and determinants. J. Finan. Res. 27(1):31-54.

30. Gneezy U, Rustichini A (2000). Pay enough or don't pay at all. Q. J. Econ., 115: 791-810.

31. Tessema M, Soeters $J$ (2006). Challenges and prospects of HRM in developing countries. Testing the HRM-performance link in Eritrean civil service. Int. J. Hum. Res. Manage., 17(1): 86-105.

32. Guest DE (2004). Flexible employment contracts, the psychological contract and employee outcomes. An analysis and review of the evidence. Int. J. Manage. Rev., 5/6 (1): 1-19.

33. Spector P (2008). Industrial and Organizational Psychology. Research and Practice, 5th ed., John Wiley \& Sons, New York,NY.

34. James D (1996). Forget Downsizing, Now It's Participative Redesign, Bus. Rev. Weekly, 18(46): 70-72.

35. Yen TH, McKinney WR (1992). The relationship between compensation satisfaction and job characteristics: $A$ comparative study of public and private leisure service professionals. J. Park Recreational Admin, p45.

36. Robbins SP, Odendaal A, Roodt G (2003). "Organizational behavior", (9th ed.) Cape Town. Prentice-Hall International.

37. Ayache Zoubeir, and Dallel Adjali, (2015), "The Role of Intellectual Capital Management in Enhancing Organization' Competitiveness: An Empirical Study on Algerian Insurance Organizations", Mediterranean Journal of Social Sciences, $\operatorname{vol}(6), \mathrm{N}^{\circ}(3), \mathrm{p} 317$.

38. Ibd, p318. 